\title{
Isolation and Identification of Fungi Caused Data Palms Inflorescence Rot Disease in Some Area of Diyala- Iraq and Control of Disease by Sodium Chloride Salt
}

\author{
Rabab Majead Abed, Gassan Radam Idan, Roqia Ahmed Abbas and Nagham \\ Thayir Salman \\ Department of Biology, College of Pure Science and Education, Diyala University, Diyala, Iraq.
}

\begin{abstract}
This work was carried out in Diyala Province, North of Baghdad, Iraq during 2016-2017 to isolation and identification the fungi caused Inflorescence rot on data palm and try to combat the disease by using sodium chloride salt. 32 infected samples were collected from 8 varieties of data palm which has been isolated 60 isolates of fungi belong to 6 genus and species of fungi which were Mauginiella scattae, Fusarum proliferum, Penicillum chrysogenum, Rhizopus spp., Mucor spp. and Aspergillus niger, the number of isolates for each one were $(20,12,10,6,6,6)$ respectively. $M$. scattae showed highest percentage of frequency and occurrence that $(33.33,65.63) \%$, while $F$. proliferum recorded the lowest percentage of frequency and occurrence which were $(6.66,18.75) \%$. Treatment with the sodium chloride salt gave significant reduction in Inflorescence rot on all data palm varieties. Disease incidence and percentage of Infection, which were $0 \%$ in all data palm varieties excepting khistawi variety which recorded $(22.22,33.33) \%$ respectively for while control treatment recorded $(100,100) \%$ respectively for Disease incidence and percentage of Infection. This confirms the possibility of using sodium chloride salt as a substitute for chemical fungicides.
\end{abstract}

Keywords: Inflorescence rot, sodium chloride, Disease incidence, frequency, Mauginiella scattae.

*Correspondence: rabab.majead81@gmail.com

(Received: 12 December 2018; accepted: 30 January 2019)

Citation: Rabab Majead Abed, Gassan Radam Idan, Roqia Ahmed Abbas and Nagham Thayir Salman, Isolation and Identification of Fungi Caused Data Palms Inflorescence Rot Disease in Some Area of Diyala- Iraq and Control of Disease by Sodium Chloride Salt, J Pure Appl Microbiol., 2019; 13(1):459-463 doi: 10.22207/JPAM.13.1.51

(C) The Author(s) 2019. Open Access. This article is distributed under the terms of the Creative Commons Attribution 4.0 International License which permits unrestricted use, sharing, distribution, and reproduction in any medium, provided you give appropriate credit to the original author(s) and the source, provide a link to the Creative Commons license, and indicate if changes were made. 


\section{INTRODUCTION}

In Iraq the main problems of data palm (Phoenix dactylifera L.) are exposed to many diseases and pests that effect on fruit production but nature and severity The problems vary by cultivar, location, weather, and cultural practices, These diseases caused by different type of pathogens like fungi, insect, nematode. (Zaid et al. 2002; Al-Jboory 2007).

Inflorescence rot is one of these disease which transmission during the infection season occurs through the contamination of male inflorescences during the pollination period and the first symptoms occur at the external surface of unopened spathes especially if emerges early in the spring season with typical brownish or rusty color lesion, Infected inflorescences remaining on palms from the previous season or infected leaf bases may serve to spread the disease (Abdullah et al. 2005).

The first recorded of it in Iraq in 1949 by Hanford this disease caused by Mauginiella scattae fungus (Al-Ani et al. 1971). Some studies recorded another fungi along with Mauginiella scattae such as Thielaviopsis paradoxa and Fusarium moniliforme (Dherbi 1983), in some area of Thi-Qar in Iraq The main reason of this disease was Mauginiella scattae and another fungi which were Fusarium spp., Aspergillus spp., Penicillium spp., Acremonium spp., and Mucor spp. (Al Ghilan 2012), In Hameed (2012) study found that the causal organism of data palm inflorescence rot disease in southern part of Iraq is Fusarium proliferatum .

For development of novel, more effective, safe and environmental friendly antifungal agents as an alternative to the chemical fungicides used for combating a variety of crop diseases is currently an environmental challenge. In Diyala - Iraq there were few and old studies That looked at this disease and its pathogenical causes there for the current study aimed to isolation and identification of fungi which caused inflorescence rot disease on data palms Phoenix dactylifera L. and using Sodium Chloride salt to fight disease on the trees.

\section{MATERIALS AND METHODS}

\section{Sample collections}

Several visits to some palm date orchards in Al-Migdadiyah in Diyala, Iraq In the flowering season of the data palm in 2016-17, were carried out to collect samples. A total of 32 samples were collected from 8 varieties of data palm that infected with inflorescence rot disease, each sample was placed in plastic bags and data were recorded in terms of the variety and number of infected palm, then the samples were stored in a laboratory refrigerator at $5-7^{\circ} \mathrm{C}$ until the isolation. Isolation of the pathogen

Small pieces from each infected inflorescence ( $2 \mathrm{~cm}$ long) were surface-sterilized with $10 \%$ sodium hypochloride for $5 \mathrm{~min}$, then wash with sterilized distilled water and dried on filter paper than3 pieces were placed onto plates containing potato dextrose agar (PDA) Added to it chloramphenicol $200 \mathrm{mg} / \mathrm{L}$ and each sample with 3 replicates. All plates were incubated at 25 $\pm 1^{\circ} \mathrm{C}$ until the fungus started growth. A hyphal tip for each isolate was excised on to a PDA plate to establish its colony. Single spore technique was used to ensure the purity of cultures. Isolated fungi were identified based on the morphological characters in culture. The identification was based on (Ellis 1971; Alexoplulos et al. 1996; Barnett and Hunter 1998). Percentage of appearance for each isolated fungi are calculated according to the following formula (Krebs 1978):

The Percentage of occurrence $(\%)=\mathrm{N}$. of sample which has the same genera or species $/ \mathrm{N}$. of total samples of genera or species.

Percentage of frequency calculated according to formula (Krebs 1978)

The Percentage of frequency $(\%)=$ No. of isolate for fungus / No. of total isolates for all fungi Treatment with Sodium Chloride salt

The infected data palm trees were treated with Sodium Chloride ascoarse salt at $1 \mathrm{Kg} /$ tree, the salt was sprayed on the sites of infection in the trees and the control treatment was left without salt spray. The spraying was carried out in two stages the first of January2016 and the second in March 2017. After the completion of the exit and cracking all the spathes on all the palm the Disease incidence and Infection percent was scored according to the formulas:

Disease incidence $=($ No. of infected date palms / No. of total date palms) $\times 100$

$\%$ Infection= (No. of Infected spathes /

No. of total spathes ) $\times 100$ 


\section{Statistical Analysis}

For statistical analysis SPSS version $\mathbf{1 7 . 0}$ was used, The comparison between the averages using Less Significant Difference test (LSD) Least Significant Deference at the level of probability of 0.05 .

\section{RESULTS AND DISCUSSION}

Six genus and species of fungi were isolated and identification from Infected spathes of data palm Phoenix dactylifera $\mathrm{L}$. which collected from fields of Al-Migdadiyah in Diyala, Iraq, These fungi include Mauginiella scattae, Fusarium proliferum, Penicillum chrysogenum, Rhizopus spp., Mucor spp. and Aspergillus niger. The number of fungal isolates was 60 isolates from 32 infected samples, M. scattae (20) isolate, Mucor spp. (12) isolate, A. niger (10) isolate and $F$. proliferum, $P$. chrysogenum, Rhizopus spp. recorded (6) isolate for each one (Table 1).

In (Figure 1) showed the percentage of frequency and occurrence of isolated fungi, $M$. scattae showed highest percentage of occurrence which was (65.63) \% Followed by fungi A.niger, $P$. chrysogenum, Mucor spp., Rhizopus spp. and $F$. proliferum which were recorded (56.25, 37.5, 37.5, $28.13,18.75) \%$ Respectively. for percentage of frequency, $M$. scattae showed highest percentage of frequency which was (33.33) \%, then A.niger, Mucor spp., Rhizopus spp., P. chrysogenum, F. proliferum which were $(20,20,13.33,6.66,6.66)$ $\%$ Respectively.
The results of isolating the fungi showed a difference in the causes of inflorescence rot disease this agree with Al-Ghilan (2012) study which showed more than one cause of inflorescence rot and which were Mauginiella scattae, Fusarium spp., Aspergillus spp., Penicillium spp. Acremonium spp. and Mucor spp. some studies showed that only Mauginiella scattae fungi caused this disease (Hameed 2005; Hassen 2010), another study found that the main caused of this disease in Southern Iraq was Fusarium proiferatum (Hameed 2012). Al-Sharidi and Al-Shahwan. (2003) recorded two caused of inflorescence rot disease that Mauginiella scattae and Thielaviopsis paradoxa.

The results in (Table 2) Showed the possibility of using salt effectively to reduce inflorescence rot disease on all data palm

Table 1. Isolated fungi from infected spathes of data palm Phoenix dactylifera L. that caused inflo-rescence rot disease in Diyala, Iraq.

\begin{tabular}{lc}
\hline Isolated fungi & $\begin{array}{c}\text { Number of } \\
\text { isolates }\end{array}$ \\
\hline Mauginiellascatta & 20 \\
Fusariumproliferatium & 6 \\
Rhizopus sp. & 6 \\
Mucor sp. & 6 \\
Penicillumchrysogenum & 12 \\
Aspergillusniger & 12 \\
Total & 60 \\
L.S.D at 0.05 & 1.155 \\
\hline
\end{tabular}

Table 2. Percentage of infection and disease indicated on some varieties of data palm Phoenix dactylifera L. after traded with coarse salt.

\begin{tabular}{|c|c|c|c|c|c|c|}
\hline \multirow[t]{2}{*}{ Variety } & \multirow{2}{*}{$\begin{array}{l}\text { Total No. } \\
\text { of palms }\end{array}$} & \multirow{2}{*}{$\begin{array}{l}\text { Total No. } \\
\text { of spaths }\end{array}$} & \multicolumn{2}{|c|}{$\begin{array}{l}\text { Total No. of spaths } \\
\text { after treatment } \%\end{array}$} & \multirow{2}{*}{$\begin{array}{l}\% \text { disease } \\
\text { infection }\end{array}$} & \multirow[b]{2}{*}{ indicated } \\
\hline & & & Infected & Healthy & & \\
\hline Zahdi & 6 & 10.33 & 0 & 10.33 & 0 & 0 \\
\hline Khistawi & 4 & 9 & 2 & 7 & 22.22 & 33.33 \\
\hline Tberzal & 6 & 6.66 & 0 & 6.66 & 0 & 0 \\
\hline Khodry & 2 & 5 & 0 & 5 & 0 & 0 \\
\hline Sukkari & 6 & 4.33 & 0 & 4.33 & 0 & 0 \\
\hline Dhenh & 4 & 10.66 & 0 & 10.66 & 0 & 0 \\
\hline Breen & 2 & 8 & 0 & 8 & 0 & 0 \\
\hline Basrawe & 2 & 4 & 0 & 4 & 0 & 0 \\
\hline Control & 8 & 6.33 & 6.33 & 0 & 100 & 100 \\
\hline L.S.D at 0.05 & 3.197 & 3.127 & 3.702 & N.S. & 3.702 & 3.702 \\
\hline
\end{tabular}




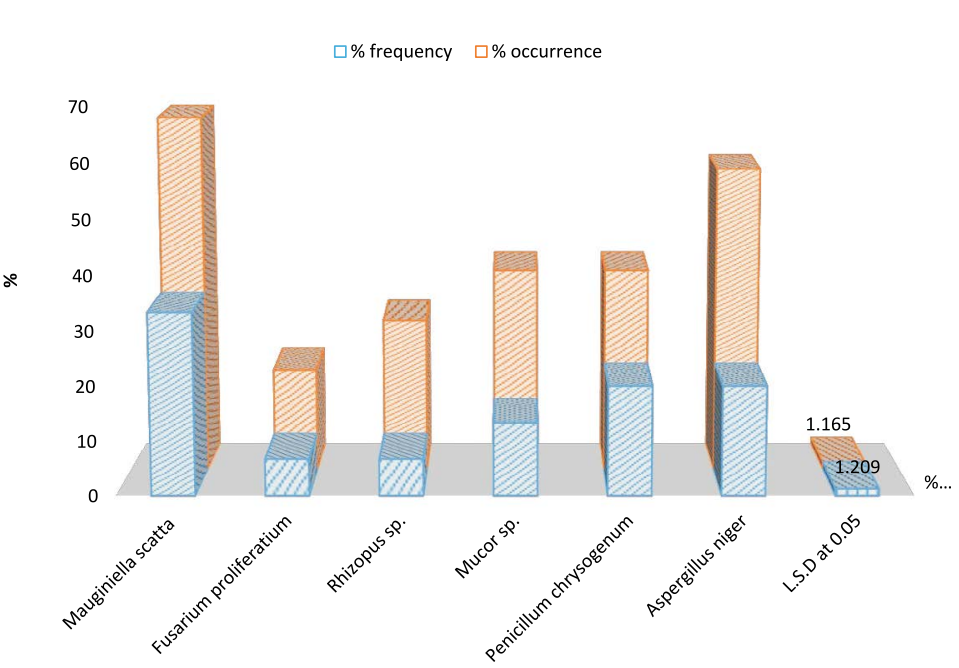

Fig. 1. The percentage of frequency and occurrence for isolated fungi from infected spathes of data palm Phoenix dactylifera L.

varieties, there were significantly reduced in Disease incidence and percentage of Infection Which were $0 \%$ in all data palm varieties excepting khistawi variety which recorded $(22.22,33.33) \%$ respectively for disease incidence and percentage of Infection compared with control treatment which was $(100,100) \%$ respectively.

The reduction in disease in current study was attributed to reduction in the growth of fungal pathogensas a result of salt treatment, in Stock-well et al. (2012) study showed the negative effects of sodium chloride on growth of some pathogenic fungi. The result of current study agree with Hassen (2010) study that found the high effective of salt against inflorescence rot disease. There was a significant decrease in percentage of Infection which was (21.5)\% compared with control treatments that (53.7) \%. Some laboratory studies confirmed showed the Inhibitory effect of $\mathrm{NaCl}$ salt on fungi growth like Aspergillus niger, Penicillium roqueforti, Alternaria alternate, Fusarium oxysporum (Reid et al. 2001; Yigit and Korukuoglu 2007).

The exact mechanisms of how $\mathrm{NaCl}$ amendments suppress disease are still unclear, but two areas where it could affect disease are those that have direct effects against the pathogen and those that have effects on the resistance of the plant (Fixen 1993). Sodium chloride may have caused a fungistatic effect in these soils and prevented the onset of pathogenesis. They suggested $\mathrm{NaCl}$ could reduce competitive saprophytic ability of the pathogen while increasing antagonistic microbes (Amir et al. 1996).

\section{ACKNOWLEDGEMENTS}

None.

\section{CONFLICT OF INTEREST}

The author declares that there are no conflict of interest.

\section{REFERENCES}

1. Krebs CJ. Ecology: The Experimental Analysis of Distribution and Abundance. Harper and Row Publisher, New York 1978.

2. Zaid A, de Wet PF, Djerbi M, Oihabi A. in Date palm cultivation, Diseases and pests of date palm, edZaid A. (Food and Agriculture Organization Plant Production and Protection Paper no. 156. Food and Agriculture Organization of the United Nations, Rome, Italy) 2002; 227-281.

3. Al-Jboory IJ. Survey and identification of the biotic factors in the date palm environmentand its application for designing IPM-Program of date palm pests in Iraq. Univ. Aden J. Nat. and Appl. Sci., 2007; 11(3): 3-10.

4. Hameed MA. Inflorescence rot disease of date palm caused by Fusarium proliferatum in Southern Iraq. African Journal of Biotechnology, 2012 ; 11(35): 86168621.

5. Al-Ani HY, El-Behadili A, Majeed HA, Majeed M. Reaction of date palm cultivars to inflorescence rot and persistency and spreading of the disease. Phytopathol. Mediterranean, 1971; 10: 57-62

6. Abdullah SK, Asensio L, Monfort E, Gomez-Vidal S, Palma-Guerrero J, Salinas J, Lopez-Llorca LV, Jansson HB, Guarro J.Occurrence in Elx, SE Spain of inflorescence rot disease of date palms caused by 
Mauginiella scaettae. J. Phytopathol., 2005; 153: 417422.

7. Hassen KA. Testing the effect od salt, cinder and some fungicides against the influence rot disease on datepalm in center of Iraq (Diyala province). Diyala Journal for pure sciences, 2010; 6(2): 509-515.

8. Hameed MA. Susceptibility of different cultivars of data palm (phoenix dactylifera L.) to Mauginiella scaettae the causal agent of inflorescnce rot. Basrah Journal for data palm research, 2005; 4(1-2): 37-53.

9. Dherbi M. Diseases of the date palm (Phoenix dactylifera L.) FAO 1983; 114

10. Al Ghilan AJK. Isolation and identification of Mauginiella scaettae Cav. Which causes data palms inflorescencr rot disease in some areas of Thi-Qar province and its sensitivity to some plant extracts. master thesis university of Thi-Qar, college of education of pure science 2012.

11. Alexoplulos CD, Mims CW and Blackwel M. Introductory Mycology, John Wiley and Sons, Incorporation 1996; 869.

12. Barnett $\mathrm{HL}$ and Hunter BB Illustrated genera of imperfect fungi. 4th ed. The American Phyto-pathology Society, 1998; 218.
13. Ellis MB. Dematiaceous, Hyphomycetes. Commonw. Mycol. Inst. Kew, England, 1971; 608.

14. Al-Sharidi AM and Al-Shahwan IM. Fungi Associated with Rot Diseases of Inflorescence and Fruit of Date Palm in Riyadh Region. Saudi Arabia. Arab J. PI. Prot., 2003; 21: 84-89.

15. Stockwell MP, Clulow J and Mahony MJ. Sodium Chloride Inhibits the Growth and Infective Capacity of the Amphibian Chytrid Fungus and Increases Host Survival Rates. Plos One, 2012; 7(5):1-7.

16. Amir H, Amir A and Riba A. Role de la microfloredans laresitance a la fusariose- vasculaire induitepar la salinitedans un sol depalmeriae. Soil Biol. Biochem., 1996; 28: 113-122.

17. Fixen PE. Crop response to chloride. Adv. Agron., 1993; 50: 107-150.

18. Yigit $A$ and Korukluoglu $M$. The effect of potassium sorbate, $\mathrm{NaCl}$ and $\mathrm{pH}$ on the growth of food spoilage fungi. Annals of Microbiology, 2007; 57(2): 209-215.

19. Reid TC, Hausbeck MK and Kizilkaya K. Effect of Sodium Chloride on commercial Asparagus and of Alternative Forms of chloride salt on Fusarium Crown and Root Rot. Plant Disease, 2001; 85(12):1271-1275. 